\title{
Economic impacts of health shocks on households in low and middle income countries: a review of the literature
}

\author{
Khurshid Alam ${ }^{1,2^{*}}$ and Ajay Mahal ${ }^{1}$
}

\begin{abstract}
Poor health is a source of impoverishment among households in low -and middle- income countries (LMICS) and a subject of voluminous literature in recent years. This paper reviews recent empirical literature on measuring the economic impacts of health shocks on households. Key inclusion criteria were studies that explored household level economic outcomes (burden of out-of-pocket (OOP) health spending, labour supply responses and non-medical consumption) of health shocks and sought to correct for the likely endogeneity of health shocks, in addition to studies that measured catastrophic and impoverishment effects of ill health. The review only considered literature in the English language and excluded studies published before 2000 since these have been included in previous reviews. We identified 105 relevant articles, reports, and books. Our review confirmed the major conclusion of earlier reviews based on the pre-2000 literature - that households in LMICs bear a high but variable burden of OOP health expenditure. Households use a range of sources such as income, savings, borrowing, using loans or mortgages, and selling assets and livestock to meet OOP health spending. Health shocks also cause significant reductions in labour supply among households in LMICs, and households (particularly low-income ones) are unable to fully smooth income losses from moderate and severe health shocks. Available evidence rejects the hypothesis of full consumption insurance in the face of major health shocks. Our review suggests additional research on measuring and harmonizing indicators of health shocks and economic outcomes, measuring economic implications of non-communicable diseases for households and analyses based on longitudinal data. Policymakers need to include non-health system interventions, including access to credit and disability insurance in addition to support formal insurance programs to ameliorate the economic impacts of health shocks.
\end{abstract}

Keywords: Health shocks, Low- and middle-income countries, Catastrophic out-of-pocket health spending, Impoverishment, Labour supply and income loss, Non-medical consumption effect, Coping strategies

\section{Introduction}

Health shocks, whether an event of death or disease, can cause significant adverse economic outcomes for households low- and middle-income countries (LMICs). Poor health among members can increase the risk of a household becoming destitute if there are significant out-ofpocket (OOP) healthcare expenditures incurred to obtain healthcare. Even if OOP treatment costs are avoided by not seeking care, the household to which a sick individual

\footnotetext{
* Correspondence: khurshid.alam@monash.edu

${ }^{1}$ Monash School of Public Health and Preventive Medicine, Monash University, The Alfred Centre, 99 Commercial Road, Level 5, Melbourne, VIC 3004, Australia ${ }^{2}$ Equity and Health Systems, International Centre for Diarrhoeal Disease Research, Bangladesh (ICDDR,B), Mohakhali, Dhaka 1212, Bangladesh
}

belongs may still forgo earnings if there are work-days lost by the sick individual or his informal caregivers. From a policy standpoint, any adverse economic outcomes of health shocks of households hinder progress on national development goals such as poverty reduction and economic growth. Excessive reliance on OOP health spending may also ration scarce healthcare services away from the less well-off to those who can afford to pay, enhancing inequalities in access to care [1]. Intergenerational equality may also be affected, if health shocks adversely influence national and household ability to contribute to child health and educational outcomes.

Analyses of the economic impacts of health shocks have been the subject of significant researcher attention

\section{Biomed Central}


in recent years, outpacing existing reviews of the economic implications of ill health, which are either limited in scope or out of date. Of the three previous reviews most relevant for this paper, Russell [2] explored the direct and indirect cost of illness related to HIV, tuberculosis and malaria; McIntyre et al. [3] focused on household level impacts of OOP medical spending and labour-days loss due to illness in the pre-2000 literature; and Acharya et al. [4] focused on protective effects of voluntary insurance from the economic implications of illness, including recent insurance interventions. However, considerable gaps remain. In particular, the post-2000 literature on the implications of illness for non-medical consumption, labour supply and informal coping mechanisms has simply not been covered in existing reviews with one exception: and that exception, Acharya et al. [4], only assessed the impacts of insurance programs on household OOP spending in LMICs.

The primary goal of this paper is to summarize recent evidence on the economic impacts of health shocks in LMICs based on the World Bank definition of LMICs as countries with a gross national income per capita less than US\$ 12,616 in 2012. The overarching research question guiding this review was: what are the economic impacts of health shocks on households in LMICs and what factors influence the magnitude of these impacts? The specific sub-questions were: what are the impacts of health shocks on OOP health payments of the households and on measures of catastrophic spending and impoverishment? What are the impacts of health shocks on labour supply and earnings of households? What are the impacts on non-medical consumption of the households? What contextual and other factors influence the magnitude of these impacts? Our review adds to earlier reviews of the literature by bringing together a large number of recent studies, and specifically during 20002014, in the LMICs of Asia, Africa, Latin America and Eastern Europe on the economic impacts of health shocks at the household level. In addition, advances in the methodology of estimating the impacts of health shocks and new ways of measuring the economic burden of illness developed in recent years mean that our review adds significantly to the information base on the household economic implications of illness. Because of the existing review by Acharya et al. [4], we only include a brief discussion of the analyses of the implications of formal insurance programs.

\section{Methods}

Figure 1 illustrates the conceptual approach that guided the current review. Specifically there are two main avenues through which impacts of health shocks are likely to be felt by households. First, households are at risk of incurring OOP health spending if they seek treatment. If the OOP spending is large, relative to say exceeding a certain threshold of a household's income or some measure of 'capacity to pay', there is the possibility that it might be 'catastrophic' in nature (see Additional file 1 for definitions) [1,5-7]. The degree to which OOP health spending is catastrophic for the households often depends on whether social protection mechanisms exist. For instance, we would expect OOP expenses to be low if good quality subsidized public facilities are accessible to households, or if there is health insurance coverage that pays for the use of health services [8]. However, OOP can also be low if households simply forgo healthcare if they are not in position to pay for it and this may have other consequences, including poor health outcomes and loss of earnings. Second, households may face a loss of productive labour time and earnings due to illness or death of their members and associated caregiver time. If illness-affected household members or their caregivers work in the formal sector, earnings losses might be limited, but this is not common in LMICs.

To limit the consequences (OOP health spending, nonmedical spending and earnings losses) of health shocks households can potentially adopt one or more of a range of strategies. These can include borrowing and sales of assets to meet expenses and earnings losses, accessing informal community-based insurance pools and formal health insurance, increase the labour force participation of young children or diversify income sources, say by better access to credit [9]. If these strategies are ineffective, households can experience significant declines in non-medical consumption, including expenditures on such items as food, education, housing and recreation. In some cases, the lowering of non-medical consumption can be so severe as to lead to the household being classified as poor (see Additional file 1) $[5,10]$. Households can also be impoverished in the longer run if sales of productive assets, borrowing and reduced educational investments impose a significant future financial outgo and lower household earnings.

\section{Search strategy}

To assess the empirical evidence available on these economic impacts, we employed a comprehensive search strategy (Figure 2) using electronic databases such PubMed/Medline, EconLit, Science Direct, Social Science Citation Index, Applied Social Sciences Index and Abstracts (ASSIA), and Social Sciences Abstracts. In these search strategies we used a range of keywords relating to economic impacts of health shocks on households and coping strategies in LMICs (health shocks/illness/ death, medical expenditure, OOP health payments, catastrophic expenditure, labour supply loss, income loss, nonmedical consumption, poverty/impoverishment, coping 


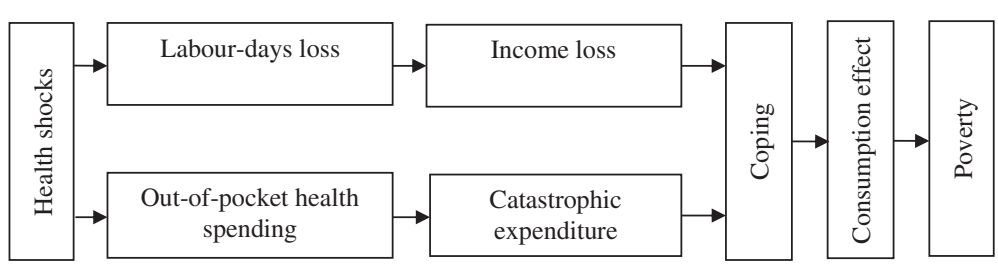

Figure 1 Conceptual framework of economic impacts of health shocks on households in low and middle income countries.

strategy). Apart from generic illness or health shocks we were also interested in specific health problems such as HIV/AIDS, adult deaths, and non-communicable diseases (NCDs) considering their importance in global disease burden and we searched on these specific health conditions combining with the aforementioned same key words.

Our inclusion criteria limited analyses to household level economic outcomes due to health shocks among households living in LMICs. Macroeconomic analyses that did not assess household or individual level economic consequences, studies conducted in developed countries, and studies published before 2000 were excluded from the analysis. Our review was further limited to literature in the English language. Crucially, we limited our attention to studies that used methods to address potential biases in estimating the impacts of health shocks on household economic outcomes. The risk of bias arises because health shocks are unlikely to be truly exogenous. Indeed, twoway causality between economic outcomes and health events (classic endogeneity), unobserved characteristics of individuals that increase both the likelihood of their being more susceptible to illness and to more severe economic outcomes, or selection into specific behaviour (unobserved heterogeneity), and poor recall (measurement errors) in reports of illness and its severity could all bias estimates of the impacts of illness. There may also be simple cases of omitted variables where inclusion of additional control variables can help. For these reasons our inclusion criteria required that the methodology employed by the authors had addressed at least one (ideally more) of the estimation challenges mentioned earlier. We limited our search to studies that had relied on instrumental variable methods, fixed-effects or random-effects approaches in the context of longitudinal data, analyses where (after controlling for appropriate variables) there could be reasonable expectation that the health shock could be treated as exogenous (including quasi-experimental methods such as propensity score matching), or methods correcting for selection effects.

There was one set of exceptions, however, to the above. We also included studies that used an accounting approach to assess economic impacts - specifically studies that calculated catastrophic and impoverishing effects associated with OOP health spending on healthcare. This was done because of the overwhelming popularity of this methodology following the initial work of Xu et al. [6] and Doorslaer et al. [10], both published in the Lancet [6,10], despite conceptual shortcomings [11].

All searches identified 7,612 references. After careful screening of the abstracts, 105 full papers were retrieved and included in the analysis because of their containing information relevant for the purposes of this review.

\section{Results}

\section{Effect on OOP health spending}

A large majority of the studies on OOP spending in the review that met our inclusion criteria focused on the catastrophic and impoverishing impacts of illness and suggest significant OOP healthcare expenses in LMICs due to health shocks (see Table 1).

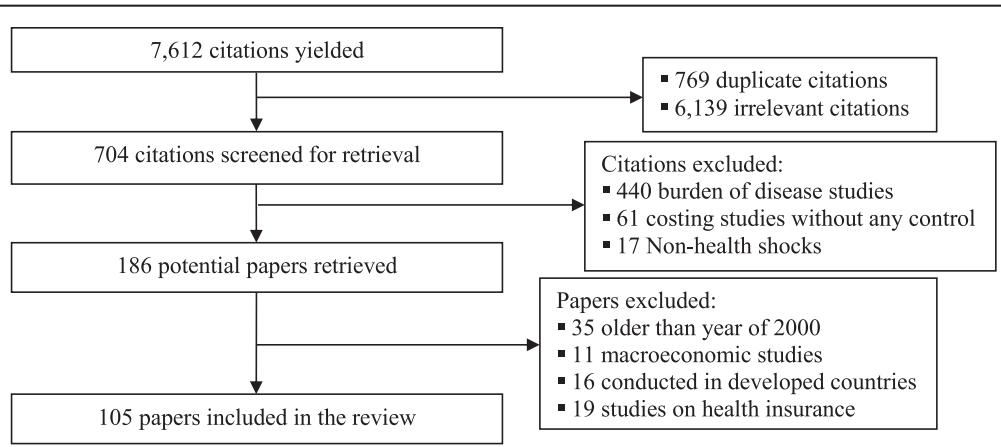

Figure 2 Search strategies for selection of studies exploring economic impacts of health shocks on households in low and middle income countries. 
Table 1 Effect of health shocks on household out-of-pocket health spending and impoverishment in low and middle income countries

\begin{tabular}{|c|c|c|c|c|}
\hline Study & Country & Data source & $\begin{array}{l}\text { Out-of-pocket health } \\
\text { expenditure (\%) }\end{array}$ & Poverty incidence (\%) \\
\hline Xu et al. 2003 [6] & 59 countries & Household surveys 1991-2000 & $0-10.45$ (40\% of CTP) & - \\
\hline Xu et al. 2007 [1] & 89 countries & Household surveys 1990-2003 & $0-10.00$ (40\% of CTP) & - \\
\hline Saksena et al. 2010 [12] & 51 countries & World Health Survey 2003 & $0.62-29.96(40 \%$ of CTP & - \\
\hline \multirow{2}{*}{$\begin{array}{l}\text { Wagstaff \& van } \\
\text { Doorslaer, } 2003 \text { [5] }\end{array}$} & \multirow[t]{2}{*}{ Vietnam } & \multirow[t]{2}{*}{ Living Standard Survey 1998} & 5.13 (40\% of CTP) & $3.40 \%{ }^{\dagger}$ \\
\hline & & & 14.20 (10\% of TE) & $0.50 \%{ }^{\ddagger}$ \\
\hline \multirow[t]{2}{*}{ Van Minh et al. 2012 [13] } & \multirow[t]{2}{*}{ Vietnam } & \multirow[t]{2}{*}{ Living Standard Survey 2010} & 4.60 (of TE) & \multirow[t]{2}{*}{$2.50 \%^{\dagger}$} \\
\hline & & & 3.90 (40\% of CTP) & \\
\hline \multirow[t]{2}{*}{ Garg \& Karan, 2009 [14] } & \multirow[t]{2}{*}{ India } & \multirow[t]{2}{*}{ Consumer Expenditure Survey 1999-00 } & 4.80 (of TE) & \multirow[t]{2}{*}{$3.24 \%^{\ddagger}$} \\
\hline & & & 10.70 (of nFE) & \\
\hline \multirow[t]{2}{*}{ Joe \& Mishra, 2009 [15] } & \multirow[t]{2}{*}{ India } & \multirow[t]{2}{*}{ Consumer Expenditure Survey 2004-05 } & 6.10 (of TE) & \multirow[t]{2}{*}{$4.40 \%{ }^{\ddagger}$} \\
\hline & & & 12.00 (of nFE) & \\
\hline \multirow[t]{2}{*}{ Bonu et al. 2007 [16] } & \multirow[t]{2}{*}{ India } & \multirow[t]{2}{*}{ Consumer Expenditure Survey 2004-05 } & 13.10 (10\% of TE) & \multirow[t]{2}{*}{$3.50 \%{ }^{\ddagger}$} \\
\hline & & & $5.10(40 \%$ of $\mathrm{nFE})$ & \\
\hline \multirow[t]{2}{*}{ Gosh, $2011[17]$} & \multirow[t]{2}{*}{ India } & \multirow[t]{2}{*}{ Consumer Expenditure Survey 2004-05 } & 5.51 (of TE) & \multirow[t]{2}{*}{$4.40 \%^{\ddagger}$} \\
\hline & & & 15.37 (10\% of TE) & \\
\hline \multirow[t]{2}{*}{ Arsenijevic et al. 2013 [18] } & \multirow[t]{2}{*}{ Serbia } & \multirow[t]{2}{*}{ Living Standard Measurement Survey 2007} & $5.00(10 \%>$ up to & \multirow[t]{2}{*}{$1.10 \%^{\dagger}$} \\
\hline & & & $20 \%$ of TE) & \\
\hline \multirow[t]{2}{*}{ ICo, RD. 2008 [19] } & \multirow[t]{2}{*}{ Philippines } & \multirow[t]{2}{*}{ Family Income and Expenditure Survey 2003} & 3.50 (10\% of TE) & \multirow[t]{2}{*}{$14.00 \%^{\dagger}$} \\
\hline & & & $3.80(10 \%$ of CTP) & \\
\hline Cavagnero et al. 2006 [20] & Argentina & $\begin{array}{l}\text { National Survey on Household Expenditure } \\
\& \text { Conditions of Life Survey 1996-97 }\end{array}$ & 5.50 (40\% of CTP) & $1.70 \%^{\dagger}$ \\
\hline Tomini \& Packard, 2011 [21] & Albania & Living Standard Measurement Survey 2008 & 13.30 (of TE) & $3.61 \%^{\dagger}$ \\
\hline Mendola et al. 2007 [22] & $\begin{array}{l}5 \text { Western Balkan } \\
\text { countries }\end{array}$ & $\begin{array}{l}\text { Living Standard Measurement } \\
\text { Surveys 2000-2005 }\end{array}$ & 1.14- 26.32 (10\% of TE) & $0.05-2.80 \%^{ \pm}$ \\
\hline van Doorslaer et al. 2006 [10] & 11 Asian countries & Household surveys 1995- 2002 & 1.37-5.49 (of TE) & $0.10-3.80 \% "$ \\
\hline & & & & $0.30-3.60 \%^{ \pm}$ \\
\hline Flores et al. 2008 [23] & India & $\begin{array}{l}\text { National Sample Survey 1995-96 } \\
\text { (Hospitalized cases) }\end{array}$ & 29.20-34.15 (10\% of TE) & $7.24-7.91 \%^{\ddagger}$ \\
\hline Su et al. 2006 [24] & Burkina Faso & $\begin{array}{l}\text { Nouna Health District Household } \\
\text { Survey 2000-01 }\end{array}$ & 8.66 ( $40 \%$ of $\mathrm{nFE})$ & - \\
\hline Gotsadze et al. 2009 [7] & Georgia & $\begin{array}{l}\text { Health Care Utilization and Expenditure } \\
\text { Survey } 2007\end{array}$ & 11.70 (40\% of CTP) & - \\
\hline O'Donnell et al. 2005 [25] & 6 Asian countries & Household surveys 1996-2002 & 2.98-15.57 (10\% of TE) & - \\
\hline van Doorslaer et al. 2007 [26] & 14 Asian countries & Household surveys 1995-2002 & 2.01-15.57 (10\% of TE) & - \\
\hline & & & $0.21-7.13$ (40\% of nFE) & \\
\hline
\end{tabular}

$\mathrm{TE}=$ total household expenditure.

CTP = 'capacity to pay'.

$\mathrm{nFE}=$ non-food expenditure.

${ }^{\ddagger}$ National poverty line.

${ }^{\dagger}$ Subsistence poverty line.

"International poverty line of US\$1.08 per day per person.

${ }^{ \pm}$International poverty line of US\$2.15 per day per person.

In LMICs in Asia, OOP payments accounted for at least $30 \%$ of total healthcare expenditure in one set of multi-country studies $[25,26]$. Such OOP health expenditures have been associated with significant numbers of households incurring catastrophic levels of spending, and impoverishment: a study for 116 countries showed that globally each year healthcare payments pushed 100 million into poverty, and an estimated 150 million people exceeding a threshold (catastrophic) ratio of health spending to household's 'capacity to pay' [1]. 
The studies summarized in Table 1 also show a fairly large variation in the impacts of illness on measures of catastrophic spending, ranging from $0 \%$ to $34 \%$ depending on the country, household survey and indicator used. Multi-country analyses by Xu et al. $[1,6]$ estimated catastrophic spending in the range of $0 \%$ to $10 \%$ across countries using household income and expenditure surveys over the period 1991-2000, whereas Saksena et al. [12] estimated cross-country catastrophic spending variation from $0.6 \%$ to $30.0 \%$ of all households using World Health Survey for 2003. There were within-country differences as well. For example, in Vietnam, the proportion of households incurring catastrophic spending (defined as OOP equal to or greater than $40 \%$ of household's 'capacity to pay') fell from $5.1 \%$ in 1998 to $3.9 \%$ in 2010, using data from Living Standards Measurement Survey [5,13]. However, aside from multi-country studies that use a similar threshold, cross-country comparisons are difficult because of the differing thresholds used for defining catastrophic spending: some studies used a threshold OOP share of total household expenditure; others used a threshold OOP share of household 'capacity to pay'; and still others defined OOP thresholds as a share of non-food expenditure. In addition, the threshold share itself varied, ranging from $10 \%$ to $40 \%$.

Estimates of the impact of illness on poverty among households also vary across countries, based on data from two multi-country studies: van Doorslaer et al. [10] for 11 Asian countries and Mendola et al. [22] for 5 East European countries, which range from $0.05 \%$ to $2.8 \%$, using the World Bank \$1/day and $\$ 2$ /day poverty line, respectively [10,22]. Individual country studies for Asia report even higher impoverishment impact of illness (3.2\%-4.4\% for India [14-17], 2.5\%-3.4\% for Vietnam [5,13], 14\% for Philippines [19]). Tomini and Packard [21] also report $3.6 \%$ of households being impoverished by ill health in Albania (higher than the range of estimates reported in Mendola et al. [22] for 5 countries in East Europe that included Albania) [21,22]. With the exception of multi-country studies, however, comparisons across countries are confounded by the varying definitions of impoverishment used in the studies. For instance, individual country studies for Albania, Argentina, India, Serbia, Philippines and Vietnam, all used nationally determined poverty lines instead of the World Bank poverty lines used in Mendola et al. [22] and van Doorslaer et al. [10] that are similar across countries [5,10,18-22]. In addition, comparisons were made difficult due to the varying years for which estimates were calculated across countries. Concerns have also arisen about the existing methodology for measuring catastrophic spending and impoverishment in the literature. This is because one does not actually observe the 'counterfactual' - that is, household economic outcomes in absence of health shocks - for those who actually spent on health. One aspect of this concern is that if poor people are less likely to seek care, the poverty impact measure derived after deducting OOP healthcare payments may be downwardly biased. There is also an alternative scenario where the measure may be upwardly biased: if richer households are more likely to be insured and poorer households have to rely on borrowing or dissaving assets [22,27]. Using Indian household survey data Flores et al. [23] showed that ignoring the associated financing (coping) strategies of households in healthcare spending underestimated overall poverty impact significantly among households containing a hospitalized member.

To get around the problem of arbitrary thresholds, some studies (see Table 1) simply used the ratio of OOP to total spending (or non-food spending) although this information is available for a smaller set of countries (compared to catastrophic thresholds), primarily in Asia. These estimates ranged from $1.4 \%$ to $6.1 \%$ for a sample of 11 LMIC Asian countries (including a multi-country study by van Doorslaer et al. [10]) [10,13-15,17,25] and 13.3\% for Albania [21]. Three studies reported OOP as a share of non-food expenditure (2 for India and one for Burkina Faso) $[14,16,24]$. Data for India also suggests that the share of OOP in total household spending rose over time from 1999-2000 to 2004-5 [14-17,23].

What are the major correlates of catastrophic spending and impoverishment, and generally higher OOP, among households? Our review of the literature also suggests that OOP spending has particularly serious effects on poor households, who tend to spend more on healthcare as share of their income compared to their richer counterparts [15,28-30]. Consequently, catastrophic health expenditure and impoverishment is disproportionately concentrated among the less well-off $[1,5,6]$. In a 5-country study of Eastern European countries, less well-off households already are disproportionately impoverished by OOP health payments despite the overall share of households experiencing catastrophic OOP healthcare spending declining [21,22]. The presence of dependents with members with disability and chronic illness, and elderly members in households are also linked to catastrophic expenses in some studies $[24,28,31]$.

OOP health expenditures could also depend on the types of health care facilities and services used by patients when insurance is unavailable. Public facilities typically involve less OOP health spending than private facilities since they are subsidized, but the quality of services of public facilities in low-income settings is poor. OOP expenditures associated with a single hospital stay in a private facility for cancer or heart disease in India accounted for between 80-90\% of annual per capita household income compared to $40 \%$ $50 \%$ of annual per capita income for care obtained at a public facility [32]. An analysis for Thailand also concluded that households using inpatient services from private 
hospitals are more likely to face impoverishment due to OOP spending [33]. Some multi-country studies have shown that OOP health spending is driven by health system characteristics such as the level of co-payments, prevalence of informal payments and the use of private providers [22]. However, the impact of insurance is less clear: in their systematic review, Acharya et al. [4] note that health insurance tends to lower OOP spending in some studies, but mostly the direction of impact is inconclusive.

\section{Adult deaths}

Available studies on the impact of adult deaths suggest that OOP spending is generally higher among households with a recent death although not always statistically significant. In Ethiopia, households experiencing mortality among adults aged 15-54 years over a three-year period incurred a 7\% higher share of health expenditure in total household spending compared to the households that did not experience mortality in that age-group [34]. In urban households of Vietnam, death of working age member in the 2 years preceding the survey led to households incurring a $27 \%$ increase in per capita medical spending in the last month which was not statistically significant differentiable from a hypothesis of no effect [35]. The recent death of any household member also increased per capita household OOP spending on healthcare by $27 \%$ in last one month in Laos [36], although again this was statistically not different from zero. In contrast, in Bangladesh the death of any household member in last two years decreased medical spending by $54 \%$ but medical spending for serious illness of any household member in last one year significantly increased by $62 \%$ [37]. Overall, the lack of statistical significance in many cases suggests that the results are best interpreted as inconclusive.

\section{HIV}

Because HIV constitutes a major chunk of the global disease burden, it is of interest to assess its economic burden on households in LMICs. Although the number of studies we could access was limited, the weight of the evidence suggests that households with an HIV-positive member incur higher levels of OOP spending. In $\mathrm{Co}^{\wedge}$ te d'Ivoire mean OOP health expenditures for the adults taking antiretroviral therapy were $\$ 24.3$ per month, with $12.3 \%$ of households incurring catastrophic health expenditures based on the criterion of $40 \%$ of the 'capacity to pay' [38]. In South India median OOP medical and non-medical expenditures for treatment and services of HIV were US\$ 122 in a reference period of six months [39] and in Malaysia, median OOP health expenditure for HIV-affected per patient per year were $14.7 \%$ of the patient's median income [40]. In Nigeria, Mahal et al. [41] found per capita OOP expenses among households with HIV patients to be significantly higher than per capita OOP expenses of similar households but without an HIV patient as member.

\section{Non-communicable conditions}

Recent studies in four South Asian countries (Bangladesh, India, Nepal and Sri Lanka) and Eastern Europe (Ukraine and Russia) show that households containing a member with NCD experienced significantly higher OOP health spending [42-44]. Two of the studies compared households containing a member with angina to a set of socioeconomically and demographically similar households but without a member with angina $[43,44]$. A third study found that the share OOP spending on healthcare in total household expenditure for households containing a member with heart disease was $16.5 \%$ higher relative to a set of socioeconomically and demographically similar households in India [45]. Mahal et al. [46] found that households containing a member with cancer experienced significantly higher OOP health expenditures per capita, relative to a set of matched controls. A study for Russia sought to correct for endogeneity to show that that households containing members with chronic diseases incur higher levels of OOP healthcare expenditure than those without [42].

\section{Effect on household labour supply and income}

Table 2 summarizes key studies identified by our review that contain evidence of the impacts of health shocks on labour supply and income. These studies highlight the use of four main indicators of health shocks in the literature: adult death in the household, a measure of disability (e.g., indicator of activities of daily living (ADLs)), changes in self-reported health and specific disease indicators (e.g., heart disease).

\section{Adult deaths}

Based primarily on small set of studies for African countries and one Asian country (see Table 2), it does appear that the effect of adult mortality is to lower labour supply in the households. However, this conclusion is clouded by the fact that the studies use varying outcome measures, ranging from work participation, labour force participation, work participation among specific demographic groups to the ratio of non-workers to workers in the household and varying reference periods. For instance, in Tanzania, men aged $20-50$ years were $66 \%$ $75 \%$ less likely to participate in wage employment in the 6 months prior to death in households that experienced an adult death due to AIDS [49]. In Bangladesh, the death of a household member in the preceding two years lowered work participation of household members by an average of 8.6 hours in the last week [37]. Additionally in South Africa, the labour supply effects are in the opposite direction of increased labour force participation among a section of household members, namely 
Table 2 Effect of health shocks on household labour supply and income in low and middle income countries

\begin{tabular}{|c|c|c|c|c|c|c|}
\hline Study & Country & Data source & Statistical model & Measure of health shocks & Labour supply effect & Income effect \\
\hline Gertler \& Gruber, 2002 [47] & Indonesia & $\begin{array}{l}\text { Indonesian Resource } \\
\text { Mobilization Study } \\
\text { panel }(1991,1993)\end{array}$ & $\begin{array}{l}\text { Ordinary Least Square (OLS), } \\
\text { Instrumental Variable (IV) }\end{array}$ & $\begin{array}{l}\text { Change in index of limitations in } \\
\text { household's head ability to perform } \\
\text { activities of daily living (ADLs). Index } \\
\text { based on a formula using self-reported } \\
\text { ability to perform basic and intermediate } \\
\text { activities of daily living. }\end{array}$ & $\begin{array}{l}(-) 7.60 \% \text { in hours relative } \\
\text { to baseline }\end{array}$ & $\begin{array}{l}(-) 10 \% \text { per capita of } \\
\text { baseline earnings }\end{array}$ \\
\hline \multirow[t]{2}{*}{ Yamano \& Jayne, 2004 [48] } & \multirow[t]{2}{*}{ Kenya } & \multirow{2}{*}{$\begin{array}{l}\text { Rural household survey } \\
\text { panel }(19997,2000)\end{array}$} & \multirow{2}{*}{$\begin{array}{l}\text { Difference-in-difference } \\
\text { (DID), OLS }\end{array}$} & \multirow{2}{*}{$\begin{array}{l}\text { Any adult death; Death of male } \\
\text { household head }\end{array}$} & & $(-) 35-40 \%$ off-farm income \\
\hline & & & & & & (-)79\%*off-farm income \\
\hline Beegle, 2005 [49] & Tanzania & $\begin{array}{l}\text { Kagera Health and } \\
\text { Development Survey } 4 \\
\text { panels (1991-1994 }\end{array}$ & $\begin{array}{l}\text { Fixed effect regression\& } \\
\text { Probit model }\end{array}$ & $\begin{array}{l}\text { Death of an adult household member } \\
\text { (15-50 years) due to AIDS }\end{array}$ & $\begin{array}{l}(-) 66-75 \% \%^{* *} \text { men's wage } \\
\text { employment within } \\
6 \text { months }\end{array}$ & $\ldots \ldots$ \\
\hline \multirow[t]{2}{*}{ Lindelow \& Wagstaff, 2005 [50] } & \multirow[t]{2}{*}{ China } & \multirow{2}{*}{$\begin{array}{l}\text { China Health and Nutrition } \\
\text { Survey panel (1991, 1993, } \\
\text { 1997, 2000) }\end{array}$} & \multirow[t]{2}{*}{ Fixed effect regression } & \multirow{2}{*}{$\begin{array}{l}\text { Worsening of self-assessed health (SAH) } \\
\text { of household head by one rating on a } \\
4 \text { point scale (excellent, good, fair and } \\
\text { poor) = small health shock; difference } \\
\text { of } 2-3 \text { ratings = 'large health shock' }\end{array}$} & (-)15\%* labour market & \multirow{2}{*}{$\begin{array}{l}(-) 6.20 \% * \text { total per capita } \\
\text { income } \\
(-) 10 \% * \text { earned per capita } \\
\text { income }\end{array}$} \\
\hline & & & & & participation & \\
\hline \multirow[t]{2}{*}{ Wagstaff, 2005 [51] } & \multirow[t]{2}{*}{ Vietnam } & \multirow[t]{2}{*}{$\begin{array}{l}\text { Vietnam Living Standard } \\
\text { Survey panel }(1993,1998)\end{array}$} & \multirow[t]{2}{*}{ Fixed effect regression } & \multirow{2}{*}{$\begin{array}{l}\text { Decline in log of average body mass } \\
\text { index (BMI) among household members } \\
\text { aged } 18 \text { plus between } 1993 \text { and } 1998\end{array}$} & & $\begin{array}{l}(-) 59.90 \% * * \text { total per capita } \\
\text { income }\end{array}$ \\
\hline & & & & & & $\begin{array}{l}(-) 102.60 \%^{* * *} \text { earned per } \\
\text { capita income }\end{array}$ \\
\hline \multirow[t]{2}{*}{ Mete \& Schultz, 2006 [52] } & \multirow[t]{2}{*}{ Taiwan } & \multirow{2}{*}{$\begin{array}{l}\text { Surveys of Health and Living } \\
\text { Status panel }(1989,1993, \\
\text { 1996) }\end{array}$} & \multirow[t]{2}{*}{ Ordered probit model } & Heart disease among elderly male; & $\begin{array}{l}(-) 27.30 \% * * * \text { labour-force } \\
\text { participation }\end{array}$ & \\
\hline & & & & Stroke among elderly male & $\begin{array}{l}(-) 72.80 \% * * * \text { labour-force } \\
\text { participation }\end{array}$ & \\
\hline \multirow[t]{2}{*}{ Wagstaff, 2007 [35] } & \multirow[t]{2}{*}{ Vietnam } & \multirow{2}{*}{$\begin{array}{l}\text { Vietnam Living Standard } \\
\text { Survey panel }(1993,1998)\end{array}$} & \multirow[t]{2}{*}{ Fixed effect regression } & \multirow{2}{*}{$\begin{array}{l}\text { Death of working age member in urban } \\
\text { areas in two or so years before the } \\
1998 \text { survey }\end{array}$} & & $(-) 26 \% * * *$ total income \\
\hline & & & & & $\ldots \ldots$. & $\begin{array}{l}(-) 36.50 \% * * * \\
\text { income }\end{array}$ \\
\hline \multirow[t]{2}{*}{ Bridges \& Lawson, 2008 [53] } & \multirow[t]{2}{*}{ Uganda } & \multirow[t]{2}{*}{$\begin{array}{l}\text { Ugandan national household } \\
\text { survey (2002-2003) }\end{array}$} & \multirow[t]{2}{*}{ Heckman two-part model } & \multirow[t]{2}{*}{$\begin{array}{l}\text { Self-reported ill health (female); Self- } \\
\text { reported ill health (male) }\end{array}$} & $\begin{array}{l}(-) 6.20^{* * *} \text { in paid } \\
\text { employment }\end{array}$ & \\
\hline & & & & & $\begin{array}{l}(-) 3.90^{* * *} \text { in paid } \\
\text { employment }\end{array}$ & \\
\hline Yamauchi et al. 2008 [54] & $\begin{array}{l}\text { South } \\
\text { Africa }\end{array}$ & $\begin{array}{l}\text { KwaZulu-Natal Income } \\
\text { Dynamics Study panel } \\
(1998,2004)\end{array}$ & $\begin{array}{l}\text { Conditional fixed effect } \\
\text { logit }\end{array}$ & $\begin{array}{l}\text { Prime-age adult ( } 20-44 \text { years) mortality } \\
\text { due to AIDS }\end{array}$ & $\begin{array}{l}(+) 20 \% \%^{* * *} \text { labour force } \\
\text { participation (adolescents } \\
\& \text { female adults) }\end{array}$ & \\
\hline \multirow[t]{2}{*}{ Khan, 2010 [37] } & \multirow[t]{2}{*}{$\begin{array}{l}\text { Bangladesh } \\
\text { (Dinajpur) }\end{array}$} & \multirow[t]{2}{*}{$\begin{array}{l}\text { SHAHAR household survey } \\
3 \text { panels (2002-2003) }\end{array}$} & \multirow[t]{2}{*}{$\begin{array}{l}\text { Fixed effect \& random } \\
\text { effect regression }\end{array}$} & \multirow{2}{*}{$\begin{array}{l}\text { Death of a household member in past } \\
2 \text { years; Serious illness of a household } \\
\text { member that prevented from doing } \\
\text { normal activities in past } 1 \text { year }\end{array}$} & $\begin{array}{l}(-) 8.63 \text { hours worked in } \\
\text { the past week }\end{array}$ & $\begin{array}{l}\text { (-)12.00\% per capita earned } \\
\text { income last month }\end{array}$ \\
\hline & & & & & $\begin{array}{l}(-) 2.61 \text { hours worked in } \\
\text { the past week }\end{array}$ & $\begin{array}{l}(-) 8.65 \% * \text { per capita earned } \\
\text { income last month }\end{array}$ \\
\hline $\begin{array}{l}\text { Ghatak \& Madheswaran, } \\
2011 \text { [55] }\end{array}$ & India & $\begin{array}{l}\text { National Sample Survey } \\
\text { (2004) }\end{array}$ & Tobit model & Not able to work due to ailment (illness) & & $\begin{array}{l}(-) 21.60 \% * * \text { annual } \\
\text { household income }\end{array}$ \\
\hline
\end{tabular}


Table 2 Effect of health shocks on household labour supply and income in low and middle income countries (Continued)

\begin{tabular}{|c|c|c|c|c|c|c|}
\hline Kadiyala et al. 2011 [34] & Ethiopia & $\begin{array}{l}\text { Panel Ethiopian Rural } \\
\text { Household Survey panel } \\
\text { (1994-1997) }\end{array}$ & $\begin{array}{l}\text { DID, Propensity Score } \\
\text { Matching (PSM) }\end{array}$ & $\begin{array}{l}\text { Prime age adult ( } 15-54 \text { years) mortality } \\
\text { between } 1994 \text { and } 1997\end{array}$ & $\begin{array}{l}(+) \text { dependency } \\
\text { ratio }=0.32^{* * *}\end{array}$ & \\
\hline \multirow[t]{2}{*}{ Rocco et al. 2011 [56] } & \multirow[t]{2}{*}{ Egypt } & \multirow{2}{*}{$\begin{array}{l}\text { Household Health Utilization } \\
\text { and Expenditure Survey, } \\
2002\end{array}$} & \multirow[t]{2}{*}{$\begin{array}{l}\text { Fixed effect regression } \\
\& I V\end{array}$} & \multirow{2}{*}{$\begin{array}{l}\text { Self-reported persistent health problem } \\
\text { (disability, disease, injury or any other } \\
\text { chronic disease) for at least } 3 \text { months } \\
\text { during last } 12 \text { months }\end{array}$} & $\begin{array}{l}(-) 26 \% * * * \text { being } \\
\text { employed }\end{array}$ & \\
\hline & & & & & $\begin{array}{l}(-) 24^{* * *} \text { hours per } \\
\text { week }\end{array}$ & \\
\hline $\begin{array}{l}\text { Omar Mahmoud \& } \\
\text { Thiele, } 2013 \text { [57] }\end{array}$ & Zambia & $\begin{array}{l}\text { Two-wave household panel } \\
(2001,2004)\end{array}$ & DID \& PSM & $\begin{array}{l}\text { Any prime age ( } 12 \text { years }+ \text { ) death } \\
\text { between } 1996 \text { and 2001, and after } \\
2001\end{array}$ & $\cdots \cdots$ & $\begin{array}{l}(-) 4000-78000 \text { (Zambian } \\
\text { Kwacha) per adult-equivalent } \\
\text { household income }\end{array}$ \\
\hline Bales, 2013 [58] & Vietnam & $\begin{array}{l}\text { Household Living Standards } \\
\text { Survey panel }(2004,2006)\end{array}$ & $\begin{array}{l}\text { Fixed effect Poisson } \\
\text { regression }\end{array}$ & $\begin{array}{l}\text { Adult (15-60 years) member bedridden } \\
\text { due to illness for } 14 \text { days or more in } \\
12 \text { months; Onset of disability (with } \\
\text { respect to sight, hearing, memory and } \\
\text { concentration, walking and climbing stairs, } \\
\text { self-care and understanding and making } \\
\text { oneself understood) }\end{array}$ & $\begin{array}{l}(-) 7.70 \% \%^{* *} \text { annual } \\
\text { workdays } \\
(-) 11.90 \% * \text { annual } \\
\text { workdays }\end{array}$ & \\
\hline
\end{tabular}

Statistical significance at the level of $1 \% * *, 5 \% * *$ and $10 \% *, \ldots . .$. .results not available. 
adolescents and women [54]. Poor Indonesian households also increased labour supply by remaining members to compensate for income losses in the face of sickness and death [59].

Labour supply and work participation effects matter because they influence household income. For this reason, some studies sought to directly estimate the impact of adult mortality on household earnings and income. However, no clear conclusions can be reached. Analyses for Vietnam and Kenya suggest significant declines in income - ranging between $25 \%$ and $40 \%$ - for a household experiencing an adult mortality $[35,48]$. However one study from Bangladesh did not find statistically significant effect of adult mortality on household income [37]. A conclusion of no statistically significant effect of adult mortality on household income per capita was also reached by a study for rural Zambia [57].

\section{Other health indicators (activities of daily living, self-assessed health, body mass index, any illness)}

Apart from adult deaths, Table 2 reports evidence of the impact of various generic health indicators (changes in level of disability, changes in self-assessed health, changes in body mass index (BMI) and any ailment) on labour supply and earnings. However, it is difficult to draw generalizable conclusions for a specific indicator given that disability and self-reported indicators as well as ailment (including severity of ailment) indicators used were very study-specific. In addition, indicators of self-reported health tend to be subjective across individuals, time and countries. Irrespective of the indicator used though, adverse health outcomes were associated with reduction in labour force participation and/or work-time. For instance, in Uganda, conditional on labour market participation, falling sick or getting injured over a 30-day reference period lowered the likelihood of being in the formal labour market by $4 \%-6 \%$ among adults [53]. A study of urban slums in Dhaka (Bangladesh) showed that more than $20 \%$ of adults out of 12 thousand interviewed took days off from work due to illness in 12 months preceding the survey [60]. In Vietnam, in households where an adult member (15-60 years) was bedridden for 2 weeks or more in the last year, annual work-days were lowered by $8 \%$ [58]. Larger health shocks are also likely to be associated with bigger income losses. While households in an Indonesian study were able to fully smooth income losses from minor illness (such as fever, respiratory congestion) and $71 \%$ of the income losses from moderate illness (defined as inability to perform intermediate ADLs: carry a heavy load for 20 meters; sweep the floor or yard; walk for 5 kilometres; take water from a well; and bend, kneel, or stoop), only $38 \%$ of the income loss from severe illness shock (defined as inability of performing basic ADLs: bathe yourself; feed yourself; clothe yourself; stand from sitting in a chair; go to the toilet; and rise from sitting on the floor) could be smoothed [47].

\section{HIV}

Available studies, mostly for Africa, show that both labour supply and earnings decline in households affected by HIV. In South Africa, incomes of HIV-affected households are $35 \%$ to $50 \%$ lower than comparable unaffected households [61]. In Namibia, weight loss as proxy for an advanced state of AIDS is associated with a reduction in work time and earned income among the uninsured [62]. In Nigeria, HIV positive people experienced a decline in work participation (by 16 days) in a one year reference period and income losses due to sickness and caregiving amounted to about $40 \%$ of the combined healthcare costs and income losses compared to matched control households [41]. As noted previously, Yamane and Jayne [48] and Beegle [49], also found significant declines in labour force participation and earnings on account of adult deaths due to AIDS in Kenya and Tanzania, respectively $[48,49]$.

\section{Non-communicable diseases}

Studies of the impacts of NCDs on labour supply and income in households in LMICs are of recent origin, but they generally show household members work- and labour force participation declining as a consequence. Abegunde and Stanciole [42] showed that chronic noncommunicable diseases were associated with reduced household income by $4.8 \%$. Work participation among adult members of households containing an individual with CVD (cancer) was about $2 \%-3 \%$ lower relative to socioeconomically and demographically similar households but without cases of CVD (cancer) [45,46]. Heart disease and stroke caused significant declines in labour force participation by $27 \%$ and $73 \%$, respectively among the elderly in Taiwan [52]. Outside of Asia - in Ukraine and in Egypt - two recent studies households containing a member with a chronic condition were likely to have lower rates of work participation $[44,56]$. It is not surprising that a member with a non-communicable condition will experience lower work participation, so that work and labour force participation by other household members is of obvious interest. However, little work exists on work force participation of non-sick household members in LMICs in the context of NCDs. Nor do we know much about the impact of health insurance on labour supply and employment in LMICs. The only recent study of which we are aware (for Thailand), showed that universal coverage discourages formal-sector employment among the Thai married men [8].

\section{Effect on household non-medical consumption}

Household earnings losses and OOP healthcare expenditure resulting from health shocks can potentially lead to 
a decline in non-medical consumption, commonly used as a welfare indicator in economic analysis. Multiple studies have examined the effect of health shocks on household non-medical consumption in Asia, Africa and Latin America as indicated in Table 3. While the results vary in the magnitude of the impacts and are difficult to compare, either because they focused on specific subpopulations, or because varying methodologies (including indicators of health shocks) were used, non-medical consumption fell in nearly two-thirds of the studies we analyzed. Specifically non-medical consumption fell in 13 out of the 20 analyses of the impacts of health shocks reported in Table 3, rose in 6 cases and the results were unclear in one case.

There is also some evidence, from Ethiopia, that betteroff households are able to protect their non-medical spending in response to health shocks [63]. At the other extreme, the very poor may be compelled to beg for survival in response to illness [60]. Gertler and Gruber [47] identified consumption effects of health shocks to be smaller where household heads are male, older and more educated and currently working. But Asfaw and Braun [64] and Dercon et al. [65] show that when head of the household is the person who is unhealthy, non-medical consumption declines sharply - ranging 15\%-35\% [64,65]. Similarly, the effect on illness on consumption depends on the type of health problem and type of health service used. For example, Wang et al. [75] found that in China, the adverse effects on consumption due to hospitalization were considerably greater than if a member suffered from a chronic disease, but was not hospitalized.

Evidence suggests that from LMIC households use a range of informal coping strategies to protect their nonmedical consumption from health shocks (see Table 4). The use of current income and savings are often the immediate household response to financing OOP healthcare expenses following an illness [61]. But households also use relatively more of current income to finance moderate levels of OOP health expenditures when they are economically better-off or if the OOP spending is not excessive [23]. In Tamil Nadu (India), 70\% of the better-off households used savings or income to finance OOP health spending compared to $55 \%$ among the poorest households [76].

Households that experience major health shocks, such as hospitalization or major illnesses (e.g., cancer, heart disease) tend to rely on borrowing or asset sales to finance their health expenditure [32,43,46,61,85-87]. Among poor households, informal borrowing, loans and sale of assets are frequently used to meet OOP healthcare spending due to common illness [23,30,73,80,82,83,88-90]. Sales of livestock were commonly used to finance healthcare in studies for Peru, Mexico and Bangladesh [72,91]. Income transfers from the broader community and the extended family are also protective of non-medical consumption as shown in a number of household level studies [42,87].

Conclusions about the impact of formal insurance mechanisms on non-medical consumption are not clearcut. Most studies of the impact of formal health insurance in LMICs do not directly focus on the impact of insurance on non-medical consumption. The reviews by Acharya et al. [4] and Ekman [92] note, however, that health insurance is associated with lower OOP spending on healthcare in some studies, but that findings are unclear or even in the opposite direction in others $[4,92]$. Other than insurance, evidence from Bangladesh and Indonesia also shows that access to micro-credit institutions can help households to insure non-medical consumption against health shocks $[69,72]$.

What emerges from studies in household inability (in many cases) to protect their non-medical consumption in response to health shocks, and the ability of better-off households to do this more effectively than their poorer counterparts are not upfront. Although households use a variety of strategies to 'cope' with the impacts of health shocks, these appear not be enough to protect their non-medical consumption. The inconclusive evidence on the impact of health insurance on OOP spending also suggests that such insurance may only provide partial protection against the impact of health shocks on non-medical consumption.

\section{Adult deaths}

Available studies on the impact of adult deaths in LMICs point to unclear effects on non-medical consumption, with some studies pointing to a decline, others to no change and in at least one case to an increase in some components of household spending. In Laos, death of a household member in previous year in the richest quintile of households reduced overall household consumption by $68 \%$ and non-food consumption by $107 \%$ [36]. In Tanzania, prime-aged adult deaths lowered annual per capita household consumption by 30\% [67]. In contrast, studies using data from Ethiopia and Bangladesh show no statistically significant effects of adult deaths on nonmedical consumption [65,71,72]. A second study in Bangladesh found death of a household member lowered household per capita food consumption by $15 \%$ but increased per capita non-food consumption by 46\% [37].

\section{HIV}

Recent studies examining household level economic effect of communicable diseases on non-medical consumption are few and findings are mixed on the direction of the effects. In a study of South African households, there were no significant differences in household non-medical consumption between HIV-affected and unaffected households [70]. The influence of HIV on consumption may, however, 
Table 3 Effect of health shocks on household non-medical consumption in low and middle income countries

\begin{tabular}{|c|c|c|c|c|c|c|c|}
\hline Study & Country & Data source & Statistical model & Measure of health shocks & $\begin{array}{l}\text { Non-medical } \\
\text { consumption }\end{array}$ & $\begin{array}{l}\text { Food } \\
\text { consumption }\end{array}$ & $\begin{array}{l}\text { Non-food } \\
\text { consumption }\end{array}$ \\
\hline $\begin{array}{l}\text { Dercon \& } \\
\text { Krishnan, } \\
2000[63]\end{array}$ & Ethiopia & $\begin{array}{l}\text { Ethiopian Rural } \\
\text { Household Survey } 3 \\
\text { panels (1994-1995) }\end{array}$ & $\begin{array}{l}\text { Generalized } \\
\text { method of } \\
\text { moments }\end{array}$ & $\begin{array}{l}\text { Females among poor Southern households are too weak to work in } \\
\text { last } 28 \text { days }\end{array}$ & $\begin{array}{l}(-) 1.70-2.30 \% * * * \\
\text { body mass index } \\
\text { (BMI) per month }\end{array}$ & $\ldots \ldots$ & . \\
\hline $\begin{array}{l}\text { Gertler \& } \\
\text { Gruber, } 2002 \\
{[47]}\end{array}$ & Indonesia & $\begin{array}{l}\text { Indonesian Resource } \\
\text { Mobilization Study } \\
\text { panel (1991, 1993) }\end{array}$ & $\begin{array}{l}\text { Ordinary Least } \\
\text { Square (OLS), } \\
\text { Instrumental } \\
\text { Variable (IV) }\end{array}$ & $\begin{array}{l}\text { Change in index of limitations in household's head ability to perform } \\
\text { activities of daily living (ADLs). Index based on a formula using self- } \\
\text { reported ability to perform basic and intermediate activities of daily } \\
\text { living }\end{array}$ & $\begin{array}{l}(-) 19.50 \% \text { per } \\
\text { capita }\end{array}$ & & \\
\hline $\begin{array}{l}\text { Asfaw \& } \\
\text { Braun, } 2004 \\
{[64]}\end{array}$ & Ethiopia & $\begin{array}{l}\text { Ethiopian Rural } \\
\text { Household survey } \\
\text { panel }(1994,1995)\end{array}$ & $\begin{array}{l}\text { Two-stage least } \\
\text { square }\end{array}$ & $\begin{array}{l}\text { Self-reported illness of household head within } 4 \text { weeks before the } \\
\text { survey }\end{array}$ & . & $\begin{array}{l}(-) 1.80 \% \text { last } \\
\text { week }\end{array}$ & $\begin{array}{l}(-) 33.59 \% * * * \\
\text { last } 4 \text { months }\end{array}$ \\
\hline \multirow[t]{2}{*}{$\begin{array}{l}\text { Dercon et al. } \\
2005[65]\end{array}$} & \multirow[t]{2}{*}{ Ethiopia } & \multirow{2}{*}{$\begin{array}{l}\text { Ethiopia Rural } \\
\text { Household Survey } \\
\text { panel }(1999,2004)\end{array}$} & \multirow[t]{2}{*}{ Panel regression } & \multirow[t]{2}{*}{$\begin{array}{l}\text { Death of head, spouse or another person; lllness of head, spouse or } \\
\text { another person }\end{array}$} & $\begin{array}{l}(+) 2.10 \% \text { per } \\
\text { capita }\end{array}$ & & \\
\hline & & & & & $\begin{array}{l}(-) 8.90 \% * \text { per } \\
\text { capita }\end{array}$ & & \\
\hline $\begin{array}{l}\text { Wagstaff, } \\
2005[51]\end{array}$ & Vietnam & $\begin{array}{l}\text { Vietnam Living } \\
\text { Standard Survey panel } \\
(1993,1998)\end{array}$ & $\begin{array}{l}\text { Fixed effect } \\
\text { regression }\end{array}$ & $\begin{array}{l}\text { Negative changes in the log of average BMI among household } \\
\text { members aged } 18 \text { plus between } 19993 \text { and } 1998\end{array}$ & .. & $\begin{array}{l}(-) 17.30 \% * \\
\text { per capita }\end{array}$ & $\begin{array}{l}(-) 16.90 \% \text { per } \\
\text { capita }\end{array}$ \\
\hline $\begin{array}{l}\text { De Weerdt \& } \\
\text { Dercon, } \\
2006[66]\end{array}$ & Tanzania & $\begin{array}{l}\text { Nyakatoke Household } \\
\text { Survey } 5 \text { panels } \\
\text { (February-December, } \\
\text { 2000) }\end{array}$ & IV-regression & Medical expenditure and reduced labour supply due to due to illness & $\begin{array}{l}(-) 7.30 \% * \text { per } \\
\text { adult }\end{array}$ & $\begin{array}{l}(-) 4.80 \% \text { per } \\
\text { adult }\end{array}$ & $\begin{array}{l}(-) 7.80 \% \text { per } \\
\text { adult }\end{array}$ \\
\hline $\begin{array}{l}\text { Beegle et al. } \\
2008 \text { [67] }\end{array}$ & Tanzania & $\begin{array}{l}\text { Kagera Health and } \\
\text { Development Survey } \\
\text { panels (1991-2004) }\end{array}$ & $\begin{array}{l}\text { Fixed effect } \\
\text { regression, IV }\end{array}$ & Prime-aged (20-55 years) deaths due to AIDS (during 2000-2004) & $\begin{array}{l}(-) 29.80 \% * * \\
\text { annual per capita }\end{array}$ & & \\
\hline $\begin{array}{l}\text { Galiano \& } \\
\text { Vera- } \\
\text { Hernández, } \\
2008[68]\end{array}$ & Colombia & $\begin{array}{l}\text { Familias en Accion } \\
\text { household panel }(2002, \\
2003,2006)\end{array}$ & $\begin{array}{l}\text { Fixed effect } \\
\text { regression }\end{array}$ & $\begin{array}{l}\text { Any illness of adult male (aged 18-65 years) that does not let him } \\
\text { perform ADLs in last } 15 \text { days }\end{array}$ & $\begin{array}{l}(+) \cup S \$ 9.65^{* * *} \\
\text { monthly }\end{array}$ & $\begin{array}{l}(+) \cup S \$ 4.46 * \\
\text { monthly }\end{array}$ & $\begin{array}{l}(+) \cup S \$ 3.87^{* *} \\
\text { monthly }\end{array}$ \\
\hline \multirow[t]{2}{*}{$\begin{array}{l}\text { Gertler et al. } \\
2009[69]\end{array}$} & \multirow[t]{2}{*}{ Indonesia } & \multirow[t]{2}{*}{$\begin{array}{l}\text { Indonesian Family Life } \\
\text { Survey panel (1993, } \\
\text { 1997) }\end{array}$} & \multirow[t]{2}{*}{ Panel regression } & \multirow[t]{2}{*}{$\begin{array}{l}\text { Limitations in husband's ADLs; Limitations in wife's ADLs. Index based } \\
\text { on a formula using self-reported ability to perform basic and intermedi- } \\
\text { ate activities of daily living. }\end{array}$} & $\begin{array}{l}(-) 21.90 \% \\
\text { monthly per } \\
\text { capita }\end{array}$ & & \\
\hline & & & & & $\begin{array}{l}(-) 17.20 \% \% \\
\text { monthly per } \\
\text { capita }\end{array}$ & & \\
\hline $\begin{array}{l}\text { Khan, } 2010 \\
{[37]}\end{array}$ & $\begin{array}{l}\text { Bangladesh } \\
\text { (Dinajpur) }\end{array}$ & $\begin{array}{l}\text { SHAHAR household } \\
\text { survey } 3 \text { panels (2002- } \\
\text { 2003) }\end{array}$ & $\begin{array}{l}\text { Fixed effect } \\
\text { regression }\end{array}$ & Death of any household member in past two years & $\ldots \ldots$ & $\begin{array}{l}(-) 15.30 \%^{*} \\
\text { log per capita } \\
\text { in last } 3 \text { days }\end{array}$ & $\begin{array}{l}(+) 45.50 \%^{* *} \\
\text { log per capita } \\
\text { in last month }\end{array}$ \\
\hline $\begin{array}{l}\text { Linnemayr, } \\
2010[70]\end{array}$ & South Africa & $\begin{array}{l}\text { Household survey } 6 \\
\text { panels (2001-2003) }\end{array}$ & OLS & $\begin{array}{l}\text { HIV non-affected household screened in last month; HIV affected } \\
\text { households screened in last month }\end{array}$ & $\begin{array}{l}(+) 27.70 \% * * * \\
\text { monthly total }\end{array}$ & $\begin{array}{l}(+) 25 \% \\
{ }^{* * *} \text { monthly } \\
\text { total }\end{array}$ & $\begin{array}{l}(+) 26.20 \% \%^{* * *} \\
\text { monthly total }\end{array}$ \\
\hline
\end{tabular}


Table 3 Effect of health shocks on household non-medical consumption in low and middle income countries (Continued)

\begin{tabular}{|c|c|c|c|c|c|c|c|}
\hline & & & & & $\begin{array}{l}(+) 2 \% \text { monthly } \\
\text { total }\end{array}$ & $\begin{array}{l}(+) 2.20 \% \\
\text { monthly total }\end{array}$ & $\begin{array}{l}(+) 2.20 \% \\
\text { monthly total }\end{array}$ \\
\hline $\begin{array}{l}\text { Wagstaff \& } \\
\text { Lindelow, } \\
2010 \text { [36] }\end{array}$ & Laos & $\begin{array}{l}\text { Multi-shock cross- } \\
\text { section survey (2008) }\end{array}$ & OLS & $\begin{array}{l}\text { Death of any household member in last } 12 \text { months in the } \\
\text { richest quintile }\end{array}$ & $\begin{array}{l}(-) 67.90 \% * * * \\
\text { annual per capita }\end{array}$ & $\begin{array}{l}(-) 18.80 \% \\
\text { annual per } \\
\text { capita }\end{array}$ & $\begin{array}{l}(-) 107.20 \% \text { *** } \\
\text { annual per } \\
\text { capita }\end{array}$ \\
\hline \multirow[t]{2}{*}{$\begin{array}{l}\text { Alem \& } \\
\text { Söderbom, } \\
2012 \text { [71] }\end{array}$} & \multirow[t]{2}{*}{ Ethiopia } & \multirow[t]{2}{*}{$\begin{array}{l}\text { Household survey } \\
(2008-2009)\end{array}$} & \multirow[t]{2}{*}{ Probit regression } & \multirow[t]{2}{*}{$\begin{array}{l}\text { Self-reported illness of a family member; Death of a } \\
\text { family member }\end{array}$} & $\begin{array}{l}(+) 0.60 \% \text { per } \\
\text { adult equivalent }\end{array}$ & $\begin{array}{l}(-) 2.70 \% \text { per } \\
\text { adult } \\
\text { equivalent }\end{array}$ & \\
\hline & & & & & $\begin{array}{l}(-) 11.10 \% \text { per } \\
\text { adult equivalent }\end{array}$ & $\begin{array}{l}(-) 13.50 \% \text { per } \\
\text { adult } \\
\text { equivalent }\end{array}$ & \\
\hline \multirow[t]{2}{*}{$\begin{array}{l}\text { Islam \& } \\
\text { Maitra, } 2012 \\
\text { [72] }\end{array}$} & \multirow[t]{2}{*}{ Bangladesh } & \multirow[t]{2}{*}{$\begin{array}{l}\text { Panel household } \\
\text { survey }(1998,2000, \\
2005)\end{array}$} & \multirow[t]{2}{*}{$\begin{array}{l}\text { Fixed effect } \\
\text { regression }\end{array}$} & \multirow[t]{2}{*}{$\begin{array}{l}\text { Big expenditure/income loss due to illness; death } \\
\text { of main family earner }\end{array}$} & & $\begin{array}{l}(+) 0.02 / 100 \\
\text { Taka monthly }\end{array}$ & $\begin{array}{l}(+) 1.05 \text { per } \\
1000 \text { Taka } \\
\text { yearly }\end{array}$ \\
\hline & & & & & & $\begin{array}{l}(+) 0.31 / 100 \\
\text { Taka monthly }\end{array}$ & $\begin{array}{l}(+) 1.64 \text { per } \\
1000 \text { Taka } \\
\text { yearly }\end{array}$ \\
\hline $\begin{array}{l}\text { Powell- } \\
\text { Jackson \& } \\
\text { Hoque, } 2012 \\
\text { [73] }\end{array}$ & Bangladesh & $\begin{array}{l}\text { Household survey } 2 \\
\text { panels (2007-2008) }\end{array}$ & OLS & $\begin{array}{l}\text { Severe maternal complications (dystocia, haemorrhage, hypertensive } \\
\text { disorders of pregnancy, septic shock or septicaemia, severe anaemia) }\end{array}$ & $\begin{array}{l}(-) 5.30 \% \text { monthly } \\
\text { per capita }\end{array}$ & $\begin{array}{l}(-) 7.50 \% \\
\text { monthly per } \\
\text { capita }\end{array}$ & \\
\hline \multirow[t]{2}{*}{$\begin{array}{l}\text { Genoni, } \\
2012[74]\end{array}$} & \multirow[t]{2}{*}{ Indonesia } & \multirow[t]{2}{*}{$\begin{array}{l}\text { Indonesian Family Life } \\
\text { Survey } 2 \text { panels (1997, } \\
\text { 2000) }\end{array}$} & \multirow[t]{2}{*}{$\begin{array}{l}\text { Fixed effect } \\
\text { regression, IV }\end{array}$} & \multirow{2}{*}{$\begin{array}{l}\text { Deterioration in ability to walk } 5 \mathrm{~km} \text {; Deterioration in Intermediate } \\
\text { ADLs (carrying a heavy load for } 20 \text { meters, walking for } 5 \text { kilometers, } \\
\text { bowing or kneeling, sweeping the floor or yard, and drawing a pail of } \\
\text { water from a well) }\end{array}$} & $\begin{array}{l}(+) 1.60 \% \text { monthly } \\
\text { per capita }\end{array}$ & $\begin{array}{l}(-) 4.20 \% \\
\text { monthly per } \\
\text { capita }\end{array}$ & \\
\hline & & & & & $\begin{array}{l}(+) 1.20 \% \text { monthly } \\
\text { per capita }\end{array}$ & $\begin{array}{l}(-) 3.60 \% \\
\text { monthly per } \\
\text { capita }\end{array}$ & \\
\hline
\end{tabular}


Table 4 Coping strategies adopted by households in response to health shocks in low and middle income countries

\begin{tabular}{|c|c|c|c|c|}
\hline Study & Country & Data source & Statistical model & Measure of health shocks \\
\hline $\begin{array}{l}\text { Phung Duc \& } \\
\text { Waibe, } 2009 \\
\text { [77] }\end{array}$ & Vietnam & $\begin{array}{l}\text { Cross-sectional survey } \\
\text { data, June-August } \\
2007\end{array}$ & $\begin{array}{l}\text { Fixed effect } \\
\text { regression }\end{array}$ & $\begin{array}{l}\text { Idiosyncratic demographic shocks (death or illness of a } \\
\text { household member) since } 2002\end{array}$ \\
\hline $\begin{array}{l}\text { Kruk et al. } \\
2009[30]\end{array}$ & 40 LMICS & $\begin{array}{l}\text { World Health Survey, } \\
\text { 2002-2003 }\end{array}$ & $\begin{array}{l}\text { Multiple logistic } \\
\text { regression }\end{array}$ & Any health expenditure in last one year \\
\hline $\begin{array}{l}\text { Gertler et al. } \\
2009 \text { [69] }\end{array}$ & Indonesia & $\begin{array}{l}\text { Indonesian Family Life } \\
\text { Survey panel (1993, } \\
\text { 1997) }\end{array}$ & Panel regression & $\begin{array}{l}\text { Individual's limitations in performing ADLs. Index based or } \\
\text { a formula using self-reported ability to perform basic and } \\
\text { intermediate activities of daily living. }\end{array}$ \\
\hline $\begin{array}{l}\text { Islam \& } \\
\text { Maitra, } 2012 \\
{[72]}\end{array}$ & Bangladesh & $\begin{array}{l}\text { Panel household } \\
\text { survey }(1998,2000 \text {, } \\
\text { 2005) }\end{array}$ & $\begin{array}{l}\text { Fixed effect } \\
\text { regression }\end{array}$ & $\begin{array}{l}\text { Household incurred any big expenditure/income loss due } \\
\text { to illness in past one years; Whether the main income } \\
\text { earner died in the last one year }\end{array}$ \\
\hline $\begin{array}{l}\text { Powell- } \\
\text { Jackson \& } \\
\text { Hoque, } 2012 \\
\text { [73] }\end{array}$ & Bangladesh & $\begin{array}{l}\text { Household survey } 2 \\
\text { panels (2007-2008) }\end{array}$ & Panel regression & $\begin{array}{l}\text { Severe maternal complications (dystocia, haemorrhage, } \\
\text { hypertensive disorders of pregnancy, septic shock or } \\
\text { septicaemia, severe anaemia) }\end{array}$ \\
\hline $\begin{array}{l}\text { Dercon \& } \\
\text { Krishnan, } \\
2000 \text { [63] }\end{array}$ & Ethiopia & $\begin{array}{l}\text { Ethiopian Rural } \\
\text { Household Survey } 3 \\
\text { panels (1994-1995) }\end{array}$ & $\begin{array}{l}\text { Generalized } \\
\text { method of } \\
\text { moments }\end{array}$ & $\begin{array}{l}\text { Male or female household members are too weak to work } \\
\text { in last } 28 \text { days }\end{array}$ \\
\hline $\begin{array}{l}\text { Asfaw \& } \\
\text { Braun, } 2004 \\
{[64]}\end{array}$ & Ethiopia & $\begin{array}{l}\text { Ethiopian Rural } \\
\text { Household survey } \\
\text { panel }(1994,1995)\end{array}$ & $\begin{array}{l}\text { Two-stage least } \\
\text { square }\end{array}$ & $\begin{array}{l}\text { Self-reported illness of household head within } 4 \text { weeks } \\
\text { before the survey }\end{array}$ \\
\hline $\begin{array}{l}\text { Park, } 2006 \\
{[78]}\end{array}$ & Bangladesh & $\begin{array}{l}\text { Matlab Health and } \\
\text { Socioeconomic } \\
\text { Survey, } 1996\end{array}$ & $\begin{array}{l}\text { Two-stage least } \\
\text { squares \& } \\
\text { Instrumental } \\
\text { Variable }\end{array}$ & $\begin{array}{l}\text { Income shocks out of death or illness of household } \\
\text { members }\end{array}$ \\
\hline $\begin{array}{l}\text { Sparrow et } \\
\text { al. } 2012[79]\end{array}$ & Indonesia & $\begin{array}{l}\text { Socio-economic } \\
\text { survey panel (2003, } \\
\text { 2004) }\end{array}$ & $\begin{array}{l}\text { Fixed effect } \\
\text { regression }\end{array}$ & $\begin{array}{l}\text { Household welfare affected during the last year by an } \\
\text { event related to illness }\end{array}$ \\
\hline $\begin{array}{l}\text { Abegunde \& } \\
\text { Stanciole, } \\
2008[42]\end{array}$ & Russia & $\begin{array}{l}\text { Life Standards } \\
\text { Measurement Survey } \\
\text { (8 rounds: 1997-2004) }\end{array}$ & $\begin{array}{l}\text { Two-part Heckit } \\
\text { model }\end{array}$ & Adults reporting chronic disease \\
\hline $\begin{array}{l}\text { Nguyen et al. } \\
2012[80]\end{array}$ & Vietnam & $\begin{array}{l}\text { Survey on } 706 \\
\text { households (2008) }\end{array}$ & $\begin{array}{l}\text { Multiple logistic } \\
\text { regression }\end{array}$ & Hospitalization \\
\hline $\begin{array}{l}\text { Raccanello } \\
\text { et al. } 2007 \\
\text { [81] }\end{array}$ & Mexico & $\begin{array}{l}\text { Survey on } 400 \\
\text { pawnshop users, } 2005\end{array}$ & Probit regression & Health expenditure due to persistence health shocks \\
\hline $\begin{array}{l}\text { Modena and } \\
\text { Gilbert, } 2011 \\
\text { [82] }\end{array}$ & Indonesia & $\begin{array}{l}\text { Family Life Survey, } \\
1993\end{array}$ & $\begin{array}{l}\text { Poisson } \\
\text { Multinomial } \\
\text { Model }\end{array}$ & Demographic shocks (family deaths or illness) \\
\hline
\end{tabular}

Coping strategies

US\$17 borrow per month, **US\$4 asset sale and ***US\$4.4

transfer per month compared to normal delivery to fully

$11 \%-13 \% * * *$ higher number of income sources used

***African households $87 \%$ and Southeast Asian households $61 \%$ more likely (compare to European households) to borrow or sell assets to finance health expenditure

***Smaller effects on consumption for households within $1 \mathrm{~km}$ of financial institution compared to within $10 \mathrm{~km}$ or more

${ }^{* *}$ Access to microcredit helps to insure consumption

smooth consumption

Household with more land are able to insure consumption

Able to protect food consumption using own production and gifts

**Relationship between neighbours and relatives helps in pooling risks to smooth food consumption

$15 \% * * *$ used borrowing; $9 \% * * *$ used selling assets:

22\%*** used family assistance; $9 \%{ }^{* * *}$ reduced consumption

$7 \%$ \%** increase in transfer income (gifts) per increase in household number of chronic diseases

Odds ratio $=18^{* *}$ (using loans):

Odds ratio $=44^{*}$ (reducing food consumption)

(+) households used pawning to finance OOP health expenditure**
(+) taking loans***;
$(+)$ selling assets ${ }^{* * *}$
(+) using family assistance ${ }^{* * *}$ 
Table 4 Coping strategies adopted by households in response to health shocks in low and middle income countries (Continued)

\begin{tabular}{|c|c|c|c|c|c|}
\hline \multirow{3}{*}{$\begin{array}{l}\text { Debebe et al. } \\
\text { [83] }\end{array}$} & \multirow[t]{3}{*}{ Ethiopia } & \multirow{3}{*}{$\begin{array}{l}\text { Household survey, } \\
2011\end{array}$} & \multirow[t]{3}{*}{ Probit regression } & \multirow[t]{3}{*}{ (self-reported illness, death or disability) } & (+) 15\%*** borrowed; \\
\hline & & & & & (+) $17 \% * * *$ used savings; \\
\hline & & & & & (+) $17 \%^{* * *}$ sold assets; \\
\hline \multirow{2}{*}{$\begin{array}{l}\text { Dhanaraj, } \\
2014[84]\end{array}$} & \multirow{2}{*}{$\begin{array}{l}\text { India } \\
\text { (Andhra } \\
\text { Pradesh) }\end{array}$} & \multirow{2}{*}{$\begin{array}{l}\text { Young Lives survey } \\
\text { panel }(2006,2009)\end{array}$} & \multirow{2}{*}{$\begin{array}{l}\text { Multinomial } \\
\text { logistic regression }\end{array}$} & \multirow{2}{*}{$\begin{array}{l}\text { Serious illness or death of father affected household } \\
\text { economy negatively since the interviewer's last visit }\end{array}$} & (+) 49\%*** labour supply; (-) 93\% *** consumption; \\
\hline & & & & & (+) 53\% borrowed or sold assets; (+) 54\% received help \\
\hline $\begin{array}{l}\text { Alam \& } \\
\text { Mahal, } 2014 \\
{[43]}\end{array}$ & $\begin{array}{l}4 \text { South } \\
\text { Asian } \\
\text { countries }\end{array}$ & $\begin{array}{l}\text { World Health Survey, } \\
2002-2003\end{array}$ & $\begin{array}{l}\text { Propensity Score } \\
\text { Matching (PSM) }\end{array}$ & Diagnosed or symptomatic angina & $\begin{array}{l}\text { (+) } 6-10 \%^{* *} \text { households borrowed or sold assets to finance } \\
\text { OOP health expenditure }\end{array}$ \\
\hline
\end{tabular}


have inter-generational consequences and some studies have tried to address this point. Specifically, two studies (also for South Africa) concludes that HIV-affected households in South Africa withdraw children from schools and spend less on food which might contribute to malnutrition $[54,61]$.

\section{Non-communicable diseases}

These too, are relatively limited, although a number of studies have recently become available for India. Karan et al. [45] show that households containing members with heart disease had lower per capita non-medical consumption (by 5 international dollars) over a 15-day reference period compared to set of socioeconomically and demographically similar households that did not contain a member with heart disease. Similar methods were also applied to compare households containing a member with cancer with a set of matched controls and the results showed that that households containing a member with cancer experienced lower non-medical consumption expenditure (by 66-85 Indian Rupees per household member) compared to matched control households for over a 15-day reference period [46]. However, a multi-country study in South Asia showed that non-medical consumption among households containing a member with angina did not statistically differ from socioeconomically and demographically similar households that did not contain a member with angina [43].

\section{Conclusions}

The paper analyzed a large recent literature to explore the latest empirical findings for measuring the economic impacts of health shocks on households and the coping strategies. In the last decade, international literature in this area has tremendously grown covering more countries than ever from Asia, Africa, Latin America and some parts of Eastern Europe because of more availability of household level data. This has led existing reviews of the impacts of ill health in LMICs becoming both out of date and also geographically limited in their coverage.

Our main conclusions can roughly be summarized as follows. First, in the absence of formal health insurance households in LMICs tend to bear a high burden of OOP health expenditure, although there are considerable cross-country variations in household outcomes. This high OOP health payment for the household often stresses household's 'capacity to pay' and pushes many households into poverty. Moreover, the economic burden of OOP health payments tends to be concentrated among the poor. In sum, protecting households from OOP health payments and subsequent catastrophic shocks continues to be a major health policy problem $[1,6]$.

Second, difficulties in comparability across countries and studies notwithstanding, the overarching conclusion from the studies reviewed in this paper is that health shocks are likely to significantly reduce labour-days and labour income of the households in LMICs. Moreover, the adverse impacts are higher for health shocks of greater magnitude. The findings of the review about the impacts of health shocks on income losses are less clear with some studies showing a decline and others no effect at all.

A third, a conclusion is that the evidence generally rejects the assumption of full consumption insurance in the face of major health shocks. More generally, the more severe the illness, the less affected households were able to insure consumption. A few studies show that when households have access to credit at reasonable rates and they are fairly able to insure their consumption, such as when they have access to micro-credit $[69,72]$. Other household characteristics, such as socioeconomic status including age, sex, education and employment status of the household members appears also to influence consumption smoothing of the households in the face of health shocks.

Fourth, the review identified a range of strategies households adopt in order to cope with the economic consequences of health shocks in LMICs. Although the adopted coping strategies are often context specific, the current review identifies using income, savings, borrowing, using loans or mortgages, and selling assets and livestock to meet OOP health spending of the households. Intra-household labour substitution, hiring external labour, and withdrawing children from schools are commonly used to compensate lost labour-days and income of the households. Also, access to informal credit from relatives, land ownership, and reducing non-medical consumption are used to protect the consumption (or food consumption, as appropriate) of the households.

The review did not explicitly look at the role of health insurance mechanisms in addressing household economic outcomes owing to the recent work of Acharya et al. [4]. However, as noted in that review, while there is some evidence of OOP reduction owing to insurance, there is cross-country variability and indeed evidence in some cases that OOP spending is unchanged or even rising in response to insurance. Very few studies have look at the implications of insurance for non-medical spending.

Finally, from a methodological perspective, the review noted that the comparability of the findings across countries and over time was hampered in many cases by the use of different indicators of the burden of OOP spending both within and across countries and different studies. A similar problem arose in the use of multiple indicators of labour supply used as outcomes, ranging from work participation to labour force participation and sometimes limited to specific age groups. In the absence of a counterfactual (household economic outcomes in the absence of illness) and inapplicability of randomized experiments to studying the impacts of disease means that the search for 
improved methods for identifying the impacts of illness is likely to continue.

Our review builds on previous reviews on the impacts of health shocks in multiple ways. The number of studies and countries covered in the group of LMICs is considerably larger than in previous work, much of it based on the pre-2000 literature. Moreover, it covers new topics not covered in previous work, including the emerging literature on impoverishment impacts of health and the implications of health shocks for non-medical consumption. The much larger pool of studies that we could choose them also meant that this review could limit itself to studies that met certain methodological thresholds, as in Acharya et al. [4]. Methodological differences notwithstanding, some of the findings of this review are similar to those in the previous review by McIntyre et al. [3] that OOP spending does frequently impoverish households, that adverse economic implications on households are influenced by the economic status of the household and severity of illness, and that households respond with a variety of coping strategies in response to health shocks similar to those we find. Nonetheless, we believe our review helps rest these conclusions on a much stronger empirical foundation than previously. As in previous reviews, there is always the risk of bias arising from the fact that studies reporting significant findings are more likely to be published.

Our review also helps shed some light on appropriate policy action and research avenues to pursue. Because the severity of health shocks, household economic status and health system characteristics matter for outcomes, policy makers will need to consider these factors in tailoring their social protection policies for specific sub-groups. Policy makers also need to consider non-health sector mechanisms, such as introducing of disability insurance, safety nets, or supporting existing informal mechanisms for the protection of households against losses in income and consumption from health shocks. Future research can answer the feasibility and effectiveness of such mechanisms in protecting low-income households from the overall economic consequences of health shocks. Other areas where research can be fruitfully directed, based on this review, include harmonization of indicators used for assessing health shocks and economic outcomes. Because these in turn reflect the exigencies of available data, there may be a need to better harmonize survey instruments as in the case of Living Standards Measurement Surveys and Demographic and Health Surveys. Additional work on the economic implications of NCDs for households is also needed given their current and future significance in the disease burden of LMICs. We also believe that there is scope for additional methodological work on the topics of measures of catastrophic health spending and impoverishment given the objections that multiple authors have raised about the existing methodology.

\section{Additional file}

Additional file 1: Definition of key variables.

\section{Competing interests}

The authors declare that they have no competing interests.

\section{Authors' contributions}

KA developed conceptual framework and search strategy with the guidance from AM. KA conducted the search, reviewed articles, prepared draft. AM reviewed the draft with substantive inputs on drafts of the manuscript. Both the authors read and approved the final manuscript.

\section{Authors' information}

$\mathrm{KA}$ is a doctoral student in Health Economics, and AM is his principal doctoral adviser. AM is the Finkel Chair in Global Health at Monash School of Public Health and Preventive Medicine, Monash University, Melbourne, Australia.

\section{Acknowledgements}

KA acknowledges the funding from Australian Postgraduate Award (APA) and Endeavour International Postgraduate Research Scholarship (IPRS). AM acknowledges the funding of Alan and Elizabeth Finkel Chair in Global Health.

Received: 28 March 2013 Accepted: 24 March 2014 Published: 3 April 2014

\section{References}

1. Xu K, Evans DB, Carrin G, Aguilar-Rivera AM, Musgrove P, Evans T: Protecting households from catastrophic health spending. Health Aff 2007, 26:972-983

2. Russell $\mathrm{S}$ : The economic burden of illness for households in developing countries: a review of studies focusing on malaria, tuberculosis, and human immunodeficiency virus/acquired immunodeficiency syndrome. Am J Trop Med Hyg 2004, 71:147-155.

3. McIntyre D, Thiede M, Dahlgren G, Whitehead M: What are the economic consequences for households of illness and of paying for health care in low-and middle-income country contexts? Soc Sci Med 2006, 62:858-865.

4. Acharya A, Masset Edoardo S, Taylor F, Massett E, Satija A, Burke M, Ebrahim S: The Impact of Health Insurance Schemes for the Informal Sector in Low-and Middle-Income Countries: A Systematic Review. In Policy Research Working Paper. Washington, DC: World Bank; 2013.

5. Wagstaff A, van Doorslaer E: Catastrophe and impoverishment in paying for health care: with applications to Vietnam 1993-1998. Health Econ 2003, 12:921-933.

6. Xu K, Evans DB, Kawabata K, Zeramdini R, Klavus J, Murray CJL: Household catastrophic health expenditure: a multicountry analysis. Lancet 2003, 362:111-117.

7. Gotsadze G, Zoidze A, Rukhadze N: Household catastrophic health expenditure: evidence from Georgia and its policy implications. BMC Health Serv Res 2009, 9:69.

8. Wagstaff A, Manachotphong W: Universal Health Care and Informal Labour Markets: The Case of Thailand. In Policy Research Working Paper 6116. Washington, DC: World Bank; 2012.

9. World Bank: World Development Report 2000/2001: Attacking Poverty. Oxford, New York: Oxford University Press; 2000.

10. van Doorslaer E, O'Donnell O, Rannan-Eliya RP, Somanathan A, Adhikari SR, Garg CC, Harbianto D, Herrin AN, Huq MN, Ibragimova S: Effect of payments for health care on poverty estimates in 11 countries in Asia: an analysis of household survey data. Lancet 2006, 368:1357-1364.

11. Wagstaff A: Measuring Financial Protection in Health. In Policy Research Working Paper 4554. Washington, DC: World Bank; 2008.

12. Saksena P, Xu K, Durairaj V: The Drivers of Catastrophic Expenditure: Outpatient Services, Hospitalization or Medicines? In World Health Report (2010) Background Paper, No 21. Geneva: World Health Organization; 2010.

13. Van Minh H, Kim Phuong NT, Saksena P, James CD, Xu K: Financial burden of household out-of pocket health expenditure in Viet Nam: findings 
from the national living standard survey 2002-2010. Soc Sci Med 2013, 96:258-263.

14. Garg CC, Karan AK: Reducing out-of-pocket expenditures to reduce poverty: a disaggregated analysis at rural-urban and state level in India. Health Policy Plan 2009, 24:116.

15. Joe W, Mishra US: Household Out-of-Pocket Healthcare Expenditure in India: Levels, Patterns and Policy Concerns. In Working Paper 418. Kerala, India: Centre for Development Studies; 2009.

16. Bonu S, Bhushan I, Peters DH: Incidence, Intensity, and Correlates of Catastrophic Out-of-Pocket Health Payments in India. In ERD Working Paper No. 102. Manila: Asian Development Bank; 2007.

17. Ghosh S: Catastrophic payments and impoverishment due to out-ofpocket health spending. Economic \& Political Weekly 2011, 46:63-70

18. Arsenijevic J, Pavlova M, Groot W: Measuring the catastrophic and impoverishing effect of household health care spending in Serbia. Soc Sci Med 2013, 78:17-25.

19. Ico RD: Catastrophic health care, poverty, and impoverishment in the Philippines. Philipp Rev Econ 2008, 45:109-126.

20. Cavagnero E, Carrin G, Xu K, Aguilar-Rivera AM: Health Financing in Argentina: An Empirical Study of Health Care Expenditure and Utilization. In Working Paper 8. Edited by Financing liH. Mexico: Instituto Nacional de Salud Pública; 2006.

21. Tomini S, Packard T: Are health Care Payments in Albania Catastrophic? Evidence Form ALSMS 2002, 2005 and 2008, UNU-MERIT Working Paper Series \#2011-019. Maastricht, The Netherlands: United Nations University-Maastricht Economic and social Research institute on Innovation and Technology (UNU-MERIT); 2011:1-21.

22. Mendola M, Bredenkamp C, Gragnolati M: The Impoverishing Effect of Adverse Health Events: Evidence from the Western Balkans. In Policy Research Working Paper 4444. Washington, DC: World Bank; 2007.

23. Flores $\mathrm{G}$, Krishnakumar J, O'Donnell O, van Doorslaer E: Coping with health-care costs: implications for the measurement of catastrophic expenditures and poverty. Health Econ 2008, 17:1393-1412.

24. Su TT, Kouyaté B, Flessa S: Catastrophic household expenditure for health care in a low-income society: a study from Nouna district, Burkina Faso. Bull World Health Organ 2006, 84:21-27.

25. O'Donnell O, van Doorslaer E, Rannan-Eliya RP, Somanathan A, Garg CC, Hanvoravongchai P, Huq MN, Karan A, Leung GM, Tin K: Explaining the incidence of catastrophic expenditures on health care: comparative evidence from Asia. In EQUITAP Project: Working Paper \#5. Thessaloniki, Greece: Slavic and Oriental Studies, University of Macedonia; 2005.

26. Van Doorslaer E, O'Donnell O, Rannan-Eliya RP, Somanathan A, Adhikari SR, Garg CC, Harbianto D, Herrin AN, Huq MN, Ibragimova S: Catastrophic payments for health care in Asia. Health Econ 2007, 16:1159-1184.

27. Mahal A: Health spending and poverty. Lancet 2006, 368:1308-1309.

28. Chowdhury S: Financial burden of transient morbidity: a case study of slums in Delhi. Economic \& Political Weekly 2011, 46:59.

29. Dercon S: The Impact of Economic Reforms on Rural Households in Ethiopia: A Study from 1989 to 1995. World Bank: Washington, DC; 2002.

30. Kruk ME, Goldmann E, Galea S: Borrowing and selling to pay for health care in low-and middle-income countries. Health Aff 2009, 28:1056-1066.

31. Somkotra T, Lagrada LP: Which households are at risk of catastrophic health spending: experience in Thailand after universal coverage. Health Aff 2009, 28:w467-w478.

32. Mahal A, Karan A, Engelau M: The Economic Implications of Non-Communicable Disease for India. World Bank: Washington, DC; 2010.

33. Limwattananon S, Tangcharoensathien V, Prakongsai P: Catastrophic and poverty impacts of health payments: results from national household surveys in Thailand. Bull World Health Organ 2007, 85:600-606.

34. Kadiyala S, Rogers B, Quisumbing A, Webb P: The effect of prime age adult mortality on household composition and consumption in rural Ethiopia. Food Policy 2011, 36:647-655.

35. Wagstaff A: The economic consequences of health shocks: evidence from Vietnam. J Health Econ 2007, 26:82-100.

36. Wagstaff A, Lindelow M: Are Health Shocks Different?: Evidence from a Multi-Shock Survey in Laos. In Policy Research Working Paper 5335. Washington, DC: World Bank; 2010.

37. Khan FU: Economic Consequences of Health Shocks and Coping Strategies: Evidence from Urban poor Households in Bangladesh. The Hague, The Netherlands: Erasmus University, Graduate School of Development Studies, Institute of Social Studies; 2010.
38. Beaulière $A$, Touré $S$, Alexandre $P-K$, Koné $K$, Pouhé $A$, Kouadio $B$, Journy $N$, Son J, Ettiègne-Traoré $V$, Dabis $F$ : The financial burden of morbidity in HIV-infected adults on antiretroviral therapy in Cote d'Ivoire. PLOS One 2010, 5:e11213.

39. Duraisamy P, Ganesh A, Homan R, Kumarasamy N, Castle C, Sripriya P, Mahendra V, Solomon S: Costs and financial burden of care and support services to PLHA and households in South India. AIDS Care 2006, 18:121-127.

40. Ghailan K, Jusoh A, Rizal M, Ezat S, Ibrahim F, Halil J, Aljunid S: Impact of HIV/AIDS morbidity on households economy in Malaysia. Global Journal of Health Science 2010, 2:142-153.

41. Mahal A, Canning D, Odumosu K, Okonkwo P: Assessing the economic impact of HIV/AIDS on Nigerian households: a propensity score matching approach. AIDS 2008, 22:S95-S101.

42. Abegunde DO, Stanciole AE: The economic impact of chronic diseases: how do households respond to shocks? evidence from Russia. Soc Sci Med 2008, 66:2296-2307.

43. Alam K, Mahal A: The economic burden of Angina on households in South Asia. BMC Public Health 2014, 14:179.

44. Murphy A, Mahal A, Richardson E, Moran AE: The economic burden of chronic disease care faced by households in Ukraine: a cross-sectional matching study of angina patients. Int J Equity Health 2013, 12:38.

45. Karan A, Engelgau M, Mahal A: The household-level economic burden of heart disease in India. Trop Med Int Health 2014. In press.

46. Mahal A, Karan A, Fan VY, Engelgau M: The economic burden of cancers on Indian households. PLoS One 2013, 8:e71853.

47. Gertler $\mathrm{P}$, Gruber J: Insuring consumption against illness. Am Econ Rev 2002, 92:51-70.

48. Yamano T, Jayne TS: Measuring the impacts of working-age adult mortality on small-scale farm households in Kenya. World Dev 2004, 32:91-119.

49. Beegle K: Labor effects of adult mortality in Tanzanian households. Econ Dev Cult Chang 2005, 53:655-683.

50. Lindelow M, Wagstaff A: Health Shocks in China: Are the Poor and Uninsured Less Protected? In World Bank Policy Research Working Paper No 3740. Washington, DC: World Bank; 2005.

51. Wagstaff A: The Economic Consequences of Health Shocks. In World Bank Policy Research Working Paper No 3644. Washington, DC: World Bank; 2005.

52. Mete C, Schultz T: Health and labour-force participation of the elderly in Taiwan. International Studies in Population 2006, 3:163-200.

53. Bridges S, Lawson D: Health and labour market participation in Uganda. In Discussion Paper No 2008/07. Helsinki, Finland: United Nations University, World Institute for Development Economics Research (UNU/WIDER); 2008.

54. Yamauchi F, Buthelezi T, Velia M: Impacts of prime-age adult mortality on labour supply: evidence from adolescents and women in South Africa. Oxf Bull Econ Stat 2008, 70:375-398.

55. Ghatak A, Madheswaran S: Burden of Income Loss due to Ailment in India: Evidence from NSS data. In Working Paper 269. Bangalore, India: The Institute for Social and Economic Change; 2011.

56. Rocco L, Tanabe K, Suhrcke M, Fumagalli E: Chronic diseases and labor market outcomes in Egypt. In World Bank Policy Research Working Paper 5575. Washington, DC: World Bank; 2011

57. Omar Mahmoud T, Thiele R: Does prime-age mortality reduce per-capita household income? evidence from rural Zambia. World Dev 2013, 45:51-62.

58. Bales S: Impact of Health Stocks on Household Welfare in Vietnam Estimates Using Fixed Effects Estimation. In HEFPA Working Paper No 18. Rotterdam: Institute of Health Policy \& Management, Erasmus Universiteit Rotterdam; 2013:1-36.

59. Berloffa G, Modena F: Income Shocks, Coping Strategies and Consumption Smoothing: An Application to Indonesian Data. In Working Paper No 1. Italia: Department of Economics, University of Trento; 2009

60. Pryer J, Rogers S, Rahman A: Work-disabling illness as a shock for livelihoods and poverty in Dhaka slums, Bangladesh. Int Plan Stud 2005, 10:69-80.

61. Bachmann M, Booysen F: Health and economic impact of HIV/AIDS on South African households: a cohort study. BMC Public Health 2003, 3:14

62. Gustafsson-Wright E, Janssens W, van der Gaag J: The inequitable impact of health shocks on the uninsured in Namibia. Health Policy Plan 2011, 26:142-156.

63. Dercon $S$, Krishnan P: In sickness and in health: risk sharing within households in rural Ethiopia. J Polit Econ 2000, 108:688-727. 
64. Asfaw A, Von Braun J: Is consumption insured against illness? Evidence on vulnerability of households to health shocks in rural Ethiopia. Econ Dev Cult Chang 2004, 53:115-129.

65. Dercon S, Hoddinott J, Woldehanna T: Shocks and consumption in $\mathbf{1 5}$ Ethiopian villages, 1999-2004. J Afr Econ 2005, 14:559.

66. De Weerdt J, Dercon S: Risk-sharing networks and insurance against illness. J Dev Econ 2006, 81:337-356.

67. Beegle K, De Weerdt J, Dercon S: Adult mortality and consumption growth in the age of HIV/AIDS. Econ Dev Cult Chang 2008, 56:299-326.

68. Galiano A, Vera Hernández M: Health Shocks, Household Consumption and Child Nutrition. In WP-EC 2008-14. Paseo Sagasta: University of Zaragoza; 2008:1-29.

69. Gertler P, Levine DI, Moretti E: Do microfinance programs help families insure consumption against illness? Health Econ 2009, 18:257-273.

70. Linnemayr S: Consumption smoothing and HIV/AIDS: The case of two communities in South Africa. Econ Dev Cult Chang 2010, 58:475-506.

71. Alem Y, Söderbom M: Household-level consumption in urban Ethiopia: the effects of a large food price shock. World Dev 2012, 40:146-162.

72. Islam A, Maitra P: Health shocks and consumption smoothing in rural households: does microcredit have a role to play? J Dev Econ 2012, 97:232-243.

73. Powell-Jackson T, Hoque ME: Economic consequences of maternal illness in rural Bangladesh. Health Econ 2012, 21:796-810.

74. Genoni ME: Health shocks and consumption smoothing: Evidence from Indonesia. Econ Dev Cult Chang 2012, 60:475-506.

75. Wang $H$, Zhang L, Hsiao W: III health and its potential influence on household consumptions in rural China. Health Policy 2006, 78:167-177.

76. Vaishnavi SD, Dash U: Catastrophic payments for health care among households in urban Tamil Nadu, India. J Int Dev 2009, 21:169-184.

77. Phung Duc T, Waibel H: Diversification, Risk Management and Risk Coping Strategies: Evidence from Rural Households in Three Provinces in Vietnam. In Proceedings of the German Development Economics Conference. Frankfurt a.M: Leibniz Information Centre for Economics; 2009.

78. Park C: Risk Pooling between Households and Risk-Coping Measures in Developing Countries: Evidence from Rural Bangladesh. Econ Dev Cult Chang 2006, 54:423-457.

79. Sparrow R, Van de Poel E, Hadiwidjaja G, Yumna A, Warda N, Suryahadi A: Financial Consequences of III Health and Informal Coping Mechanisms in Indonesia. In Working Papers in Trade and Development. Canberra, Australia: Arndt-Corden Department of Economics, Crawford School of Public Policy, ANU College of Asia and the Pacific; 2012.

80. Nguyen KT, Hai Khuat OT, Ma S, Pham DC, Hong Khuat GT, Ruger JP: Coping with health care expenses among poor households: evidence from a rural commune in Vietnam. Social Sci Med 2012, 74:724-733.

81. Raccanello K, Anand J, Dolores EGB: Pawning for Financing Health Expenditures: do health shocks increase the probability of losing the pledge? Research in Economic Anthropology 2007, 26:151-172.

82. Modena F, Gilbert C: Shock Responses of Rural Households in Indonesia: A Multinomial Logit Analysis. Trento, Italy: Department of Economics, University of Trento; 2011.

83. Debebe ZY, Mebratie A, Sparrow R, Abebaw D, Dekker M, Alemu G, Bedi AS: Coping with Shocks in Rural Ethiopia. In ASC Working Paper 110/2013. Leiden, The Netherlands: African Studies Centre; 2013:1-35.

84. Dhanaraj S: Health Shocks and Coping Strategies. In WIDER Working Paper 2014/003. Helsinki, Finland: World Institute for Development Economics Research, United Nations University; 2014:1-28.

85. Bonu S, Rani M, Peters DH, Jha P, Nguyen SN: Does use of tobacco or alcohol contribute to impoverishment from hospitalization costs in India? Health Policy Plan 2005, 20:41-49.

86. Mohanan M: Causal effects of health shocks on consumption and debt: quasi-experimental evidence from bus accident injuries. Review of Economics and Statistics 2013, 95:673-681.

87. Mugisha F, Kouyate B, Gbangou A, Sauerborn R: Examining out-of-pocket expenditure on health care in Nouna, Burkina Faso: implications for health policy. Trop Med Int Health 2002, 7:187-196.

88. Binnendijk $E$, Koren R, Dror DM: Hardship financing of healthcare among rural poor in Orissa, India. BMC Health Serv Res 2012, 12:23.

89. Dilip T, Duggal R: Incidence of Non-fatal Health Outcomes and Debt in Urban India. In Urban Research Symposium. Washington, DC: World Bank; 2002.
90. Leive A, Xu K: Coping with out-of-pocket health payments: empirical evidence from 15 African countries. Bull World Health Organ 2008, 86:849-856C.

91. Takasaki Y, Barham BL, Coomes OT: Risk coping strategies in tropical forests: floods, illnesses, and resource extraction. Environ Dev Econ 2004, 9:203-224.

92. Ekman B: Community-based health insurance in low-income countries: a systematic review of the evidence. Health Policy Plan 2004, 19:249-270.

doi:10.1186/1744-8603-10-21

Cite this article as: Alam and Mahal: Economic impacts of health shocks on households in low and middle income countries: a review of the literature. Globalization and Health 2014 10:21.

\section{Submit your next manuscript to BioMed Central and take full advantage of:}

- Convenient online submission

- Thorough peer review

- No space constraints or color figure charges

- Immediate publication on acceptance

- Inclusion in PubMed, CAS, Scopus and Google Scholar

- Research which is freely available for redistribution 